\title{
"A Palace for the Maize": The Granary of Granaditas in Guanajuato and Neoclassical Civic Architecture in Colonial Mexico
}

\section{Luis Gordo Peláez}

Volume 38, numéro 2, 2013

Contemporary Scholarship on Latin American Art

Approches contemporaines de l'art latino-américain

URI : https://id.erudit.org/iderudit/1020795ar

DOI : https://doi.org/10.7202/1020795ar

Aller au sommaire du numéro

\section{Éditeur(s)}

UAAC-AAUC (University Art Association of Canada | Association d'art des universités du Canada)

ISSN

0315-9906 (imprimé)

1981-4778 (numérique)

Découvrir la revue

Citer cet article

Gordo Peláez, L. (2013). "A Palace for the Maize”: The Granary of Granaditas in Guanajuato and Neoclassical Civic Architecture in Colonial Mexico. RACAR : Revue d'art canadienne / Canadian Art Review, 38(2), 71-89.

https://doi.org/10.7202/1020795ar

\section{Résumé de l'article}

La construction d'un nouveau grenier ou alhóndiga à Guanajuato au Mexique, promue par l'intendant Juan Antonio de Riaño, débute en hiver 1798. Ce bâtiment devient rapidement un exemple singulier de l'architecture civique, du néoclassicisme et du buen gusto (bon goût) au Mexique de la fin du XVIII ${ }^{\mathrm{e}}$ siècle. Le projet de ce solide et bel édifice, avec " rien de superflu " selon l'architecte renommé Manuel Tolsá, implique de nombreux personnages parmi les plus distingués du Mexique colonial, dont les vicerois Branciforte et Iturrigaray, l'intendant Riaño et les architectes Juan de Dios Trinidad Pérez, Francisco Ortiz de Castro et José del Mazo y Avilés. Malgré l'évident besoin de doter Guanajuato d'un grenier plus large et mieux équipé, la construction du bâtiment suscite de nombreuses controverses, notamment parmi ceux qui la considèrent comme une dépense excessive alors que la ville manque d'infrastructure et d'architecture civique. Juan Vicente Alamán, ancien échevin de Guanajuato, exprime son désaccord avec cet édifice monumental, le décrivant comme un " palais pour le maïs ".
Tous droits réservés (C) UAAC-AAUC (University Art Association of Canada | Association d'art des universités du Canada), 2013
Ce document est protégé par la loi sur le droit d'auteur. L'utilisation des services d'Érudit (y compris la reproduction) est assujettie à sa politique d'utilisation que vous pouvez consulter en ligne.

https://apropos.erudit.org/fr/usagers/politique-dutilisation/ 


\title{
"A Palace for the Maize":' The Granary of Granaditas in Guanajuato and Neoclassical Civic Architecture in Colonial Mexico
}

\author{
Luis Gordo Peláez, Southern Methodist University
}

\begin{abstract}
Résumé
La construction d'un nouveau grenier ou alhóndiga à Guanajuato au Mexique, promue par l'intendant Juan Antonio de Riaño, débute en hiver 1798. Ce bâtiment devient rapidement un exemple singulier de l'architecture civique, du néoclassicisme et du buen gusto (bon goût) au Mexique de la fin du XVIII siècle. Le projet de ce solide et bel édifice, avec « rien de superflu » selon l'architecte renommé Manuel Tolsá, implique de nombreux personnages parmi les plus distingués du Mexique colonial, dont les vicerois Branciforte et Iturrigaray, l'intendant Riaño et les architectes Juan de Dios Trinidad Pérez, Francisco Ortiz de Castro et José del Mazo y Avilés. Malgré l'évident besoin de doter Guanajuato d'un grenier plus large et mieux équipé, la construction du bâtiment suscite de nombreuses controverses, notamment parmi ceux qui la considèrent comme une dépense excessive alors que la ville manque d'infrastructure et d'architecture civique. Juan Vicente Alamán, ancien échevin de Guanajuato, exprime son désaccord avec cet édifice monumental, le décrivant comme un « palais pour le maïs ».
\end{abstract}

$\mathrm{T}_{\mathrm{h}, \mathrm{s}}$ he history of the alhóndiga (granary) of Granaditas begins in 1793 with the first documents stating the need for a new building to store and sell grain in the Novohispanic city of Guanajuato. The alhóndiga was completed in November 1809, just months before Guanajuato turned into a battleground in the Mexican War of Independence. The solid granary thus became famous not only as an example of Neoclassical civic architecture and Enlightenment ideas of reason, order, and progress in New Spain, but as a symbol of Mexican insurgency and patriotism (fig. 1).

In 1864, following a visit by Emperor Maximilian of Hapsburg, the city tried to improve the conditions of prisoners who, until then, had been detained in the municipal jail. A new prison was needed, and the alhóndiga of Granaditas was considered a viable option because of its strength and solidity. The granary performed this new function for almost a century. This has had an impact on the study of the building and its treatment in art historiography: ${ }^{2}$ since the late nineteenth century, most historians have referred mainly to its association with Mexican independence, its external architecture's imposing appearance, and its refashioning into a prison. The works of Lucas Alamán and Lucio Marmolejo-both born in Guanajuato-were, for decades, the only printed references for the history of this granary. ${ }^{3}$ In 1966, historian José Arenas Sánchez published a study of the granary of Granaditas based on an expediente (document) preserved in the Archivo Histórico de la Universidad de Guanajuato. ${ }^{4}$ Despite the incompleteness of the transcripted expediente, this useful publication, along with the documents compiled by Luis Chávez Orozco a decade earlier, provided new and essential information about the history of this building. Using these documents as well as other manuscript and printed sources, this essay analyzes the architectural history of this alhóndiga as a representative example of public works in late Colonial Mexico and of Neoclassical art and architecture in Spanish America.

\section{Grain Supply and the Emergence of Alhóndigas in Guanajuato}

Santa Fe de Guanajuato, a four-day horse ride north of Mexico City, originated as a mining camp in the mid-sixteenth century. It is situated in El Bajío, a large region of exceptional importance for the economy of the Novohispanic viceroyalty. In addition to its mines, El Bajío was renowned for its agriculture and textile production, industries that had contributed to the settlement and development of a number of large and densely populated urban centres, such as Santiago de Quéretaro, San Miguel el Grande, Celaya, and León. By the late seventeenth century, as cities and towns such as Guanajuato grew in population and prosperity, alhóndigas served a simple function: to store and supply grain to the population, regulate its sale, and eradicate shortages. This was essential to the good governance of the colonial territories, particularly after the droughts, bad harvests, and price speculations of the regatones (small-time dealers).

The earliest report of an alhóndiga in Guanajuato dates from the late seventeenth century. In 1696, Juan de Ortega Montañés, viceroy of New Spain and bishop of Valladolid de Michoacán (present-day Morelia), granted a licence for the completion of a municipal granary and for the compilation of its ordinances. These laws were sent for approval to the new viceroy, José Sarmiento Valladares, Count of Moctezuma, on 2 January 1697.5 Despite this request, no major work was undertaken for the following four decades. Documents written a century later inform us that the "first and oldest [municipal granary in Guanajuato] was built in the Calle de Alonso after 1735 with 10,000 pesos borrowed from the Colegio Máximo de San Pedro y San Pablo in Mexico City." 6 As was customary in eighteenth-century Mexican credit mechanisms, the city of Guanajuato funded the construction of this first granary with borrowed money. The resultant granary, which also housed the municipal butcher shop, was situated near the urban centre, in a narrow and busy street at the back of the city hall and alongside Guanajuato's tempestous river. 


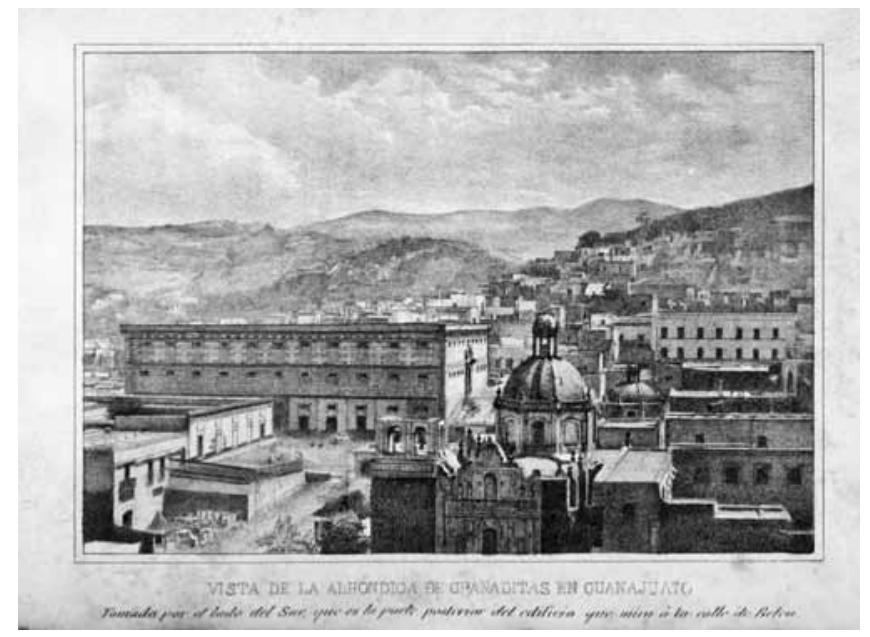

Figure I. Vista de la alhóndiga de Granaditas en Guanajuato. Tomada por el lado del Sur, que es la parte posterior del edificio que mira a la calle de Belén, 1849 (Photo: reproduced from Lucas Alamán, Historia de Méjico desde los primeros movimientos que prepararon su independencia en el año de 1808 hasta la época presente, Mexico City, I849, I, 4I0-II).

It was only on 31 March 1783 that the city council next debated the issue of the granary. Guanajuato had changed considerably by then, its peace disrupted by a devastating flood in 1760 and by the revolt in 1767 following the Jesuits' expulsion from the Spanish dominions in the Americas. 7 The city council declared that the municipal granary was in a "deplorable state" and warned that it was so deteriorated that future inclement weather could cause its collapse. ${ }^{8}$ As a precaution, the city council commissioned an "inspection and recognition of the repairs needed in the alhóndiga" from Manuel Ventura de la Cerda, master architect of public works in Guanajuato and a "person of well-known practice and intelligence." 9 To complement this report, the local authorities asked the municipal clerk to record residents' opinions of the old granary. The four residents interviewed agreed that the granary was old and damaged, and that rainstorms and floodings could cause its walls and ceilings to collapse. ${ }^{10}$

On 8 April 1783, Ventura de la Cerda submitted his report in "four useful sheets." Thanks to this document, we know that the old granary in Calle de Alonso was a building composed of two altos (storeys) and a basement. The top floor housed three rooms to store grain, a room "serving as a kitchen," and a corridor. ${ }^{11}$ The report also mentioned three entresuelos, rooms that were probably part of a lower floor conceived as a mezzanine. This floor also had a zaguán (entrance hallway), a corridor, and a zotehuela, an interior small-sized patio often found in the backs of buildings. The report was sent to Viceroy Martín de Mayorga in Mexico City, along with a request for a licence to carry out repairs to the old granary. The report suggested these could be financed by the caudal de propios, incomes from the Guanajuato municipal estates. The city council insisted that the alhóndiga could collapse at any time and warned that if repairs were not carried out immediately, the next step-the building of a new granary-would prove even more expensive. Though the viceroy's licence was granted on 23 May 1783, the original granary soon proved to be insufficient and a new building would be necessary just a few years later.

Grain shortages and price increases worsened throughout the eighteenth century-particularly in the Bajío region, where the population growth generated a greater demand for grain ${ }^{12}$ - fuelling the need for buildings that were better suited to the storage and sale of grain. Historian Lucio Marmolejo stated that after the famine of 1786, "[the city of Guanajuato] contemplated building a large granary with abundant deposits of maize, which would prevent, as far as possible, another similar calamity." 13 In those years, the viceregal authorities ordered a review of municipal revenues and expenditures in Guanajuato aiming to improve effeciency and prevent mismanagement of funds. These economic measures and a higher tax burden increased Guanajuato's financial resources, which allowed the city to engage in a number of important public works. ${ }^{14}$

\section{Intendant Riaño and the Enlightened City of Guanajuato}

By the last decade of the eighteenth century, Guanajuato had become one of the most thriving and dynamic urban centres of New Spain's Enlightenment. This cultural boom, begun years earlier with the founding and building of the Jesuit school, was further propelled by the arrival of a new intendant, Juan Antonio de Riaño y Bárcena, who assumed the government of the intendencia, or province, of Guanajuato on 28 January 1792. He replaced Andrés Amat y Tortosa who had become the province's first intendant in 1786 when the viceroyalty of New Spain had been divided into eleven new administrative regions. ${ }^{15}$ Previously, Riaño had served in the same position in the province of Michoacán, where he had arrived in 1787 after an accomplished military career and thanks to his useful kinship ties. ${ }^{16}$

Riaño was part of a brilliant generation of Spanish soldiers with an unwavering loyalty to the Crown who contributed decisively to the implementation of Bourbon reforms in Spanish America. His military training had not interfered with his intellectual interests and enlightened mind. He was an educated, prudent, and diligent man, committed to his public duties as intendant, and interested in the study and support of different academic disciplines. During his time in Guanajuato, he frequently hosted literary tertulias, gatherings that were attended by scholars such as the young Lucas Alamán and Miguel Hidalgo y Costilla, the priest of Dolores who later became famous as a leader of the Mexican War of Independence. 
Riaño's relationship with the family of Bernardo de Gálvez and his good knowledge of French culture and Enlightenment influenced his political and intellectual life. ${ }^{17}$ This enlightened world that Riaño had experienced in New Orleans was, presumably, what he sought to replicate in Valladolid and later in Guanajuato.

One of Riaño's greatest contributions as governor of Guanajuato was at the level of the infrastructure. ${ }^{18}$ In 1792, upon arriving in Guanajuato, he requested Viceroy Revillagigedo grant him permission to repair the casas reales (royal houses), the intendant's residence and seat of the city council. Their "indecent condition," he argued, made them uninhabitable "without appropriate renovation." 19 Riaño was also committed to education. He supported the work of the Royal College of the Immaculate Conception, the seminary run by the fathers of St. Philip Neri, that opened in December 1796, replacing the previous Jesuit institution. ${ }^{20}$ In 1799, José Antonio de Rojas joined the college as chair of mathematics. Educated in the viceregal capital, Rojas had a well-established career before moving to Guanajuato. He had attended the Royal Academy of San Carlos and the Royal College of Mining, New Spain's two leading academic institutions, where he had studied mathematics, humanities, and science. ${ }^{21} \mathrm{He}$ integrated studies of architectural design, botany, and minerals into his lectures. His vast knowledge allowed him to work with Alexander von Humboldt, who visited Guanajuato in 1803 as part of his scientific travels around Latin America. Humboldt participated in the city's cultural life and enlightened spirit and was warmly received by Riaño and by the city's and province's elite. In a revealing illustration of their friendly and intellectual relationship, Humboldt praised Riaño for his work and equated his thought and education with that of another brilliant figure of late colonial Mexico: "I shall merely mention the names of two enlightened men, M. de Reano, intendant of Guanaxuato, and Don Manuel Abad, penitentiary canon of the cathedral of Valladolid, whose generous and disinterested views were constantly directed towards the public good."22

Manuel Abad y Queipo lived in Michoacán at the time Riańo was intendant of that province. Abad collaborated intensely with Fray Antonio de San Miguel, who began his tenure as bishop of Valladolid in late 1784, on the promotion of various public works, including the reconstruction and extension of the city's aqueduct. Given Riaño's own beliefs, it is fair to assume that he paid close attention to these two men's commitment to the "common good," an ideal consistent with the enlightened thought and public works policy encouraged by the Spanish crown and by the viceroys of New Spain.23

Guanajuato's intellectual elite included wealthy citizens, members of the local aristocracy, and officials of the colonial administration. They supported Riaño and the city council in the public works they promoted-particularly in the construc- tion of the new alhóndiga of Granaditas-and contributed to the spread of both Enlightenment ideas and Neoclassical architecture. One of them was José Mariano de Sardaneta y Llorente. As the sole heir of the first Marquis of San Juan de las Rayas and the nephew of José Joaquín de Sardaneta y Legaspi, the first rector of Guanajuato's Jesuit college, Sardaneta had received an exceptional education in the humanities and fine arts. He had served the city council in several capacities. His privileged status and education allowed him to organize regular tertulias at his place with other intellectuals. Another was José Pérez Becerra, royal customs administrator, a man of vast culture. His excellent library, the contents of which were inventoried at his death upon Riaño's request, indicates he had good knowledge of civic architecture, visual culture, and Enlightenment thought. 24

Among this group of intellectuals promoting arts and architecture in Guanajuato, Antonio Pérez Gálvez and Diego Rul also stand out. Marmolejo praised Pérez Gálvez's commitment to the common good when he agreed to the construction of two public works, despite their negative impact on his own palace near the Plaza Mayor of Guanajuato. ${ }^{25}$ Colonel Diego Rul, ennobled in 1804 with the title of Count of Casa Rul, also owned a palace, where Humboldt had stayed, that had recently been erected in this significant city square. ${ }^{26}$ Designed, presumably, by architect Francisco Eduardo Tresguerras, this building is a fine example of New Spain's Neoclassical civil architecture (fig. 2).

Against this background of intellectual and economic effervescence, the province of Guanajuato became a significant centre for the emergence and practice of the classical architectural style promoted by the Royal Academy of San Carlos. Riaño's role in this development was pivotal. Alamán praised him not only for his interest in the fine arts, but specifically for introducing them to Guanajuato, and for promoting a "taste for them..., in particular for the architecture." Alamán credited Riaño's influence for the "magnificent buildings" that rose in the city and throughout the province and stated that the intendant "inspected their construction" and even instructed the masons on how to cut the stones. While these statements may be a little excessive, it is true that during Riaño's term, several buildings were erected in the intendencia of Guanajuato and that these followed the Neoclassical models and enlightened ideals promoted by the Mexican academy - to which Riaño was appointed honorary member in 1805.27

\section{A "Palace for the Maize:" The Site and New Granary of Granaditas}

In 1793, the city of Guanajuato stored grain in the alhóndiga on the Calle de Alonso and in ten smaller granaries, or alhondiguillas. One of them was located in a small house on the "Granaditas site," rented by the city to Ignacia de Sertuche. ${ }^{28}$ 


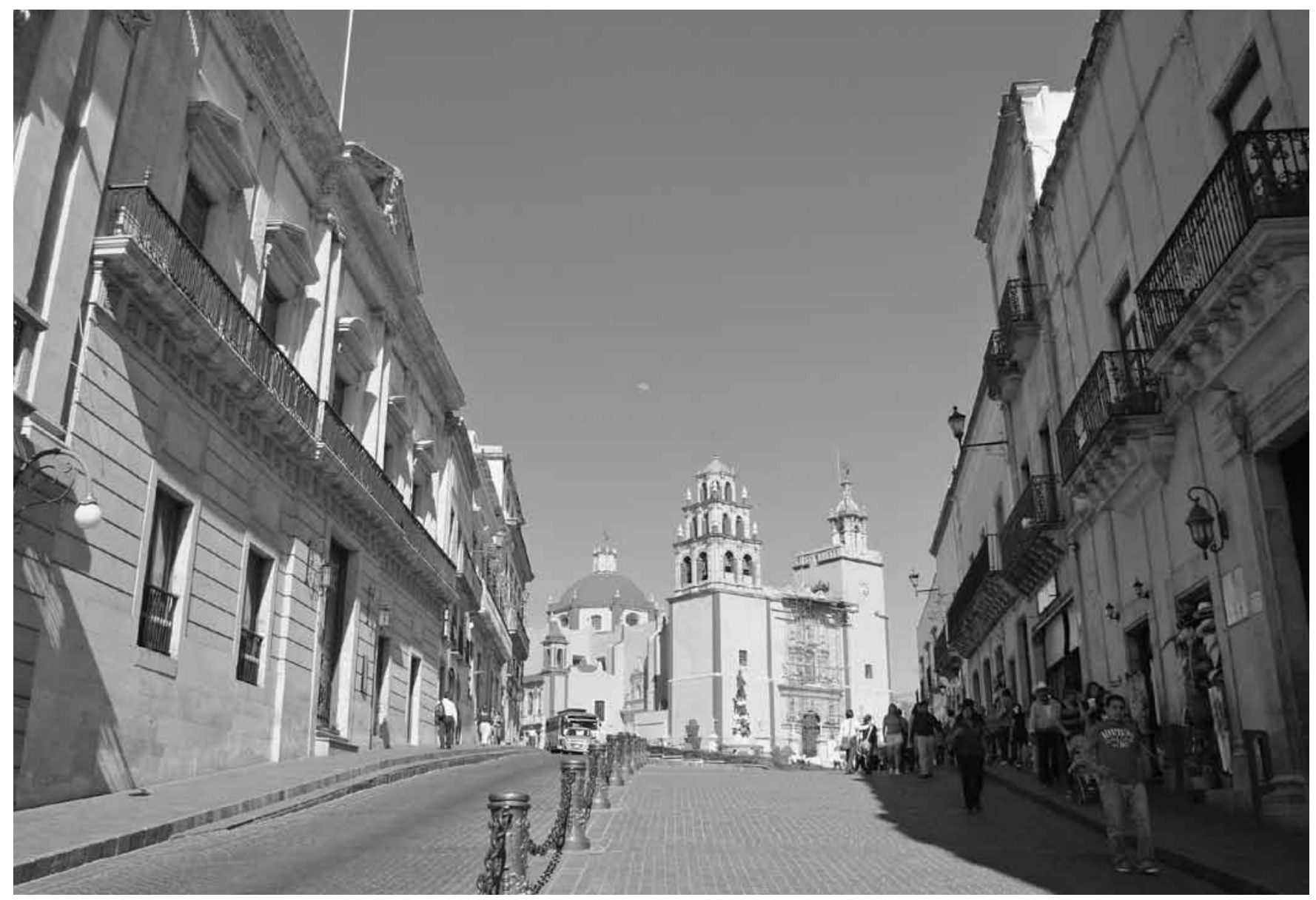

Figure 2. Plaza Mayor of Guanajuato with the houses of Diego Rul (first from left) and the Alamán family (first from right) (Photo: author).

The city council considered these granaries insufficient and inadequate, and entrusted Pedro González, the city's procurador general (legal representative), to draw up a report concerning the "urgent need" to build a new and "suitable main granary" with the "requisite rooms" to store the grain. ${ }^{29}$ The report concluded that Granaditas was the best place to build the granary, as it met the city council's requirements regarding both size and location-a large space away from the city centre, in "a high and safe place without any threat from the river." 30

González chose a group of thirteen Guanajuato residents to give their opinion. They were "subjects of the highest distinction," representatives of the city's elite, either as members of the municipal or royal bureaucracy or due to their personal wealth and professional accomplishments. ${ }^{31}$ Their testimonies backed the report's findings regarding the old granary's poor state and supported both the choice of Granaditas as a proper location and the great value and public benefit that a new building would bring to the city. 32
Procurador González's report, the witnesses's testimonies, and Riańo's own report to his superiors were sent to Mexico City along with a request for the appropriate licence. We do not know what happened to this application over the following three years. It is possible that the process was interrupted while Riaño and the city council attended to problems related to the renovation of the casas reales.

The next news regarding the alhóndiga in Guanajuato dates from 11 March 1796. Responding to an order emanating from Viceroy Branciforte, Riaño sent the viceregal capital a new report concerning the poor condition of municipal granaries in the province of Guanajuato. In it, Riaño stated that he was working on the "plan and budget" of the Guanajuato granary following the recommendations of the "distinguished city council." 33 By then, Riaño and the city council had commissioned José Alejandro Durán y Villaseñor, the city's master of public works, to prepare a design and a budget for the building of the new granary. ${ }^{34}$ Durán drew up a report dated 22 March 1796, 


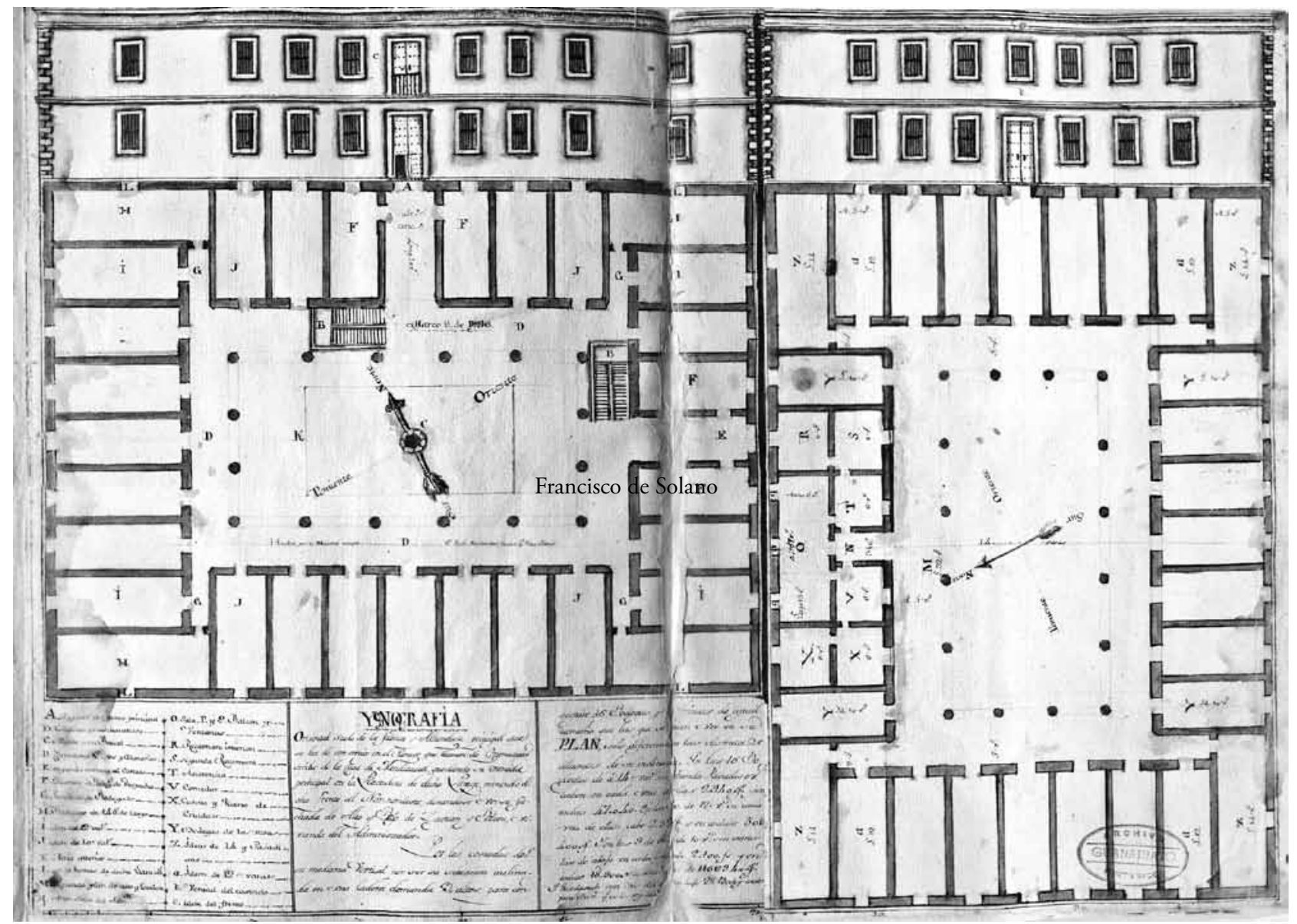

Figure 3. Plan of the new granary of Granaditas, designed by José Alejandro Durán y Villaseñor (Photo: Archivo Histórico de la Universidad de Guanajuato).

containing a plan and elevation that are the only original designs of the building preserved (fig. 3). It describes the number of rooms, the size of the rooms and façades, and the materials used in the construction, and it provides a detailed estimate of the cost.

According to the plans and report, we know that Durán designed a simple but large and solid building that coud solve the old granary's problems of space, humidity, and access. In order to facilitate the circulation of people, animals, and carriages, Durán planned the creation of wide streets around the new granary, particularly in the north and east façades, "which is where the two main entrances are." These, together with a small square or piazza in front of the building, would render the work of unloading the grain easier. Three out of the four façades would have three floors. The north façade would only have two floors due to the sloping terrain on which the granary would be built. The plan shows a rectangular-shaped building, longer in the north and south fronts. Inside, Durán planned seventy-seven rooms to store the grain, unevenly spread across the three storeys. These trojes (storerooms) would be distributed around an atrio (central courtyard) that would contain a well. Each storeroom would have a gate onto the atrio, as well as an escotillón (opening) through which the maize or wheat would be poured. Corridors or galleries would line the building towards the atrio, and would be topped by a "roof supported by columns" (fig. 4). The new building would also have two entrance corridors, on the northern and eastern sides, and two main return stairs "made of four flights and three landings" connecting the different floors of the granary. On the top floor of the north façade, Durán also included several rooms that would serve as the fiel's (granary administrator's) office and residence.

The new rooms to store the grain would have solid walls, as wide as one vara (three feet) in the basement (fig. 5). The thickness of the walls and the strength of the building's foundations were necessary to support the weight of the stored grain and to protect against humidity. In his proposal, Durán also recommended 


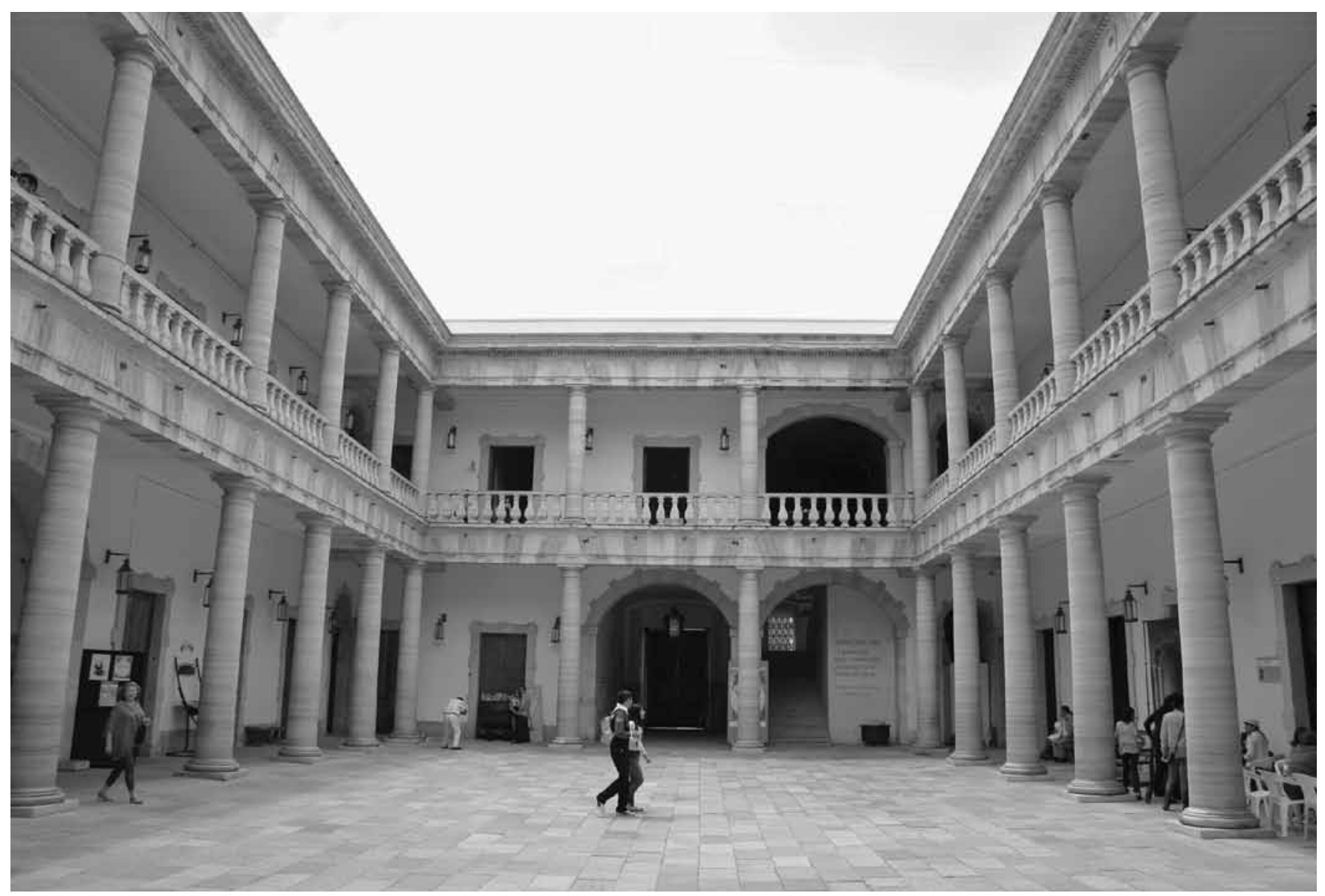

Figure 4. Granary of Granaditas, Guanajuato. Patio. Reproduction authorized by the Instituto Nacional de Antropología e Historia (Photo: author).

the use of hormigones (cement and aggregate) for the building, particularly for the construction of "vaults in the first and second floor." 35 Good quality hewn stone would be used for the patio's columns, entablatures, and lintels, the two main entrances of the building, the windows and doorframes, and the cornice crowning the four façades (fig. 6). Durán's report also mentions the use of bricks and flagstones for paving, and provides additional detail regarding construction, such as the type of roof, the carpentry work for the doors and windows, the ironwork in the building, the tools and utensils needed, the cost of additional tasks such as the clearance of space and removal of old structures, and the salary of the master architect and his workers. The total budget amounted to 164,077 pesos and one real.

In early August 1796, Riaño and the city council sent Viceroy Branciforte a petition requesting a licence to build the new granary according to Durán's design. They emphasized that the building was "almost indispensable" for the city and that it would replace the "unfit, unhealthy, and damaged" old gra- nary. They also argued that the new alhóndiga would provide a safe "supply of maize and wheat, which is the staple food of all classes of the population." Finally, they stated that the need for a new granary was such that "the people are clamouring for it." Given the high cost projected, Riaño and the city council requested permission to use the money accumulated in the Caja de Provincia, the provincial royal treasury, which would cover just over half the total amount. ${ }^{36}$ The city council planned to raise the rest of the funds during the construction of the granary through new tax revenues. Viceroy Branciforte ordered José del Mazo y Avilés_-"master in architecture of New Spain, academician of merit in the Royal Academy of San Carlos in New Spain and agrimensor titulado [surveyor]" - to re-examine the entire report. 
Neoclassicism and the Academy in Guanajuato: José del Mazo y Avilés

The late eighteenth and early nineteenth centuries were marked by a considerable expansion of the visual arts in New Spain. An illustrious group of master architects, closely linked to the Royal Academy of San Carlos, contributed to the cities' improvements of their infrastructure and public works by "modernizing" the architecture and introducing Neoclassicism. José del Mazo y Avilés was part of this dynamic group that also included, among others, Antonio González Velázquez, Miguel Constanzó, Manuel Tolsá, José Damián Ortiz de Castro, Francisco Ortiz de Castro, Ignacio Castera, José Agustín Paz, José Gutiérrez, and Joaquín de Heredia. Some of these artists had trained at the Royal Academy of San Fernando in Spain in the 1780s and early 1790s, and their appointments as directors and principal teachers of the Mexican academy undoubtedly contributed to the establishment of this new taste in Mexico City. One of the projects that reflected the triumph of Neoclassicism in Colonial Spanish America was José Damián Ortiz de Castro’s 1786 design for the completion of the Mexico City cathedral. Ortiz de Castro, who had worked with engineer and architect Miguel Constanzó, embraced contemporary architectural developments in Spain, such as Ventura Rodríguez's celebrated designs for the façade of the Pamplona Cathedral (1783).

Outside the viceregal capital, some talented figures, such as Francisco Eduardo Tresguerras and José Mariano Orińuela, also incorporated the new artistic forms and models promoted by both the Spanish Academy of San Fernando and its Mexican counterpart. The spread of Neoclassicism to the provinces was made possible by local architects' study of the classical orders and of major treatises on architecture, geometry, and arithmetic; by the presence of architects trained at the Academy of San Carlos; and by the transmission of enlightened ideas through intellectuals and bureaucrats. In some provinces, such as Guanajuato, the promotion and building of new public works in the late eighteenth century was closely linked to the arrival from Europe and Mexico City of enlightened and Neoclassical ideas. The granary of Granaditas must be seen as part of the Spanish monarchy's renewed attention to civic and educational architecture, exceptional Neoclassical examples of which can be found in both Europe and the Americas, for instance the Cabinet of Natural History in Madrid, designed by Juan de Villanueva in 1785, and the Royal Mint in Santiago de Chile, designed by Joaquín Toesca in 1782.

There is little known of Mazo's life and career, beyond a handful of buildings erected in the viceregal capital. He earned the professional qualifications of Agrimensor Titulado and Segundo Maestro Mayor de Arquitectura in Mexico City, where he mostly lived and worked. In 1790, he received the title of
Academician of Merit in the Royal Academy of San Carlos, though without taking the mandatory exam. This exemption, granted to him and others such as Ignacio Castera by Viceroy Revillagigedo, was to cause a number of controversies and disputes among architects a few years later. The information pertaining to Mazo's training and early career is incomplete, but he is usually considered to have trained with Miguel Constanzó, a military engineer of Catalan origin who worked extensively in the viceroyalty of New Spain. Mazo's contribution to the architecture and urbanism of late colonial Mexico still requires indepth research and study. 37

Mazo submitted his report on Guanajuato's new alhóndiga on 13 January 1797, "correcting" the "faults noted" in Durán's earlier report and attaching new plans and designs. 38 According

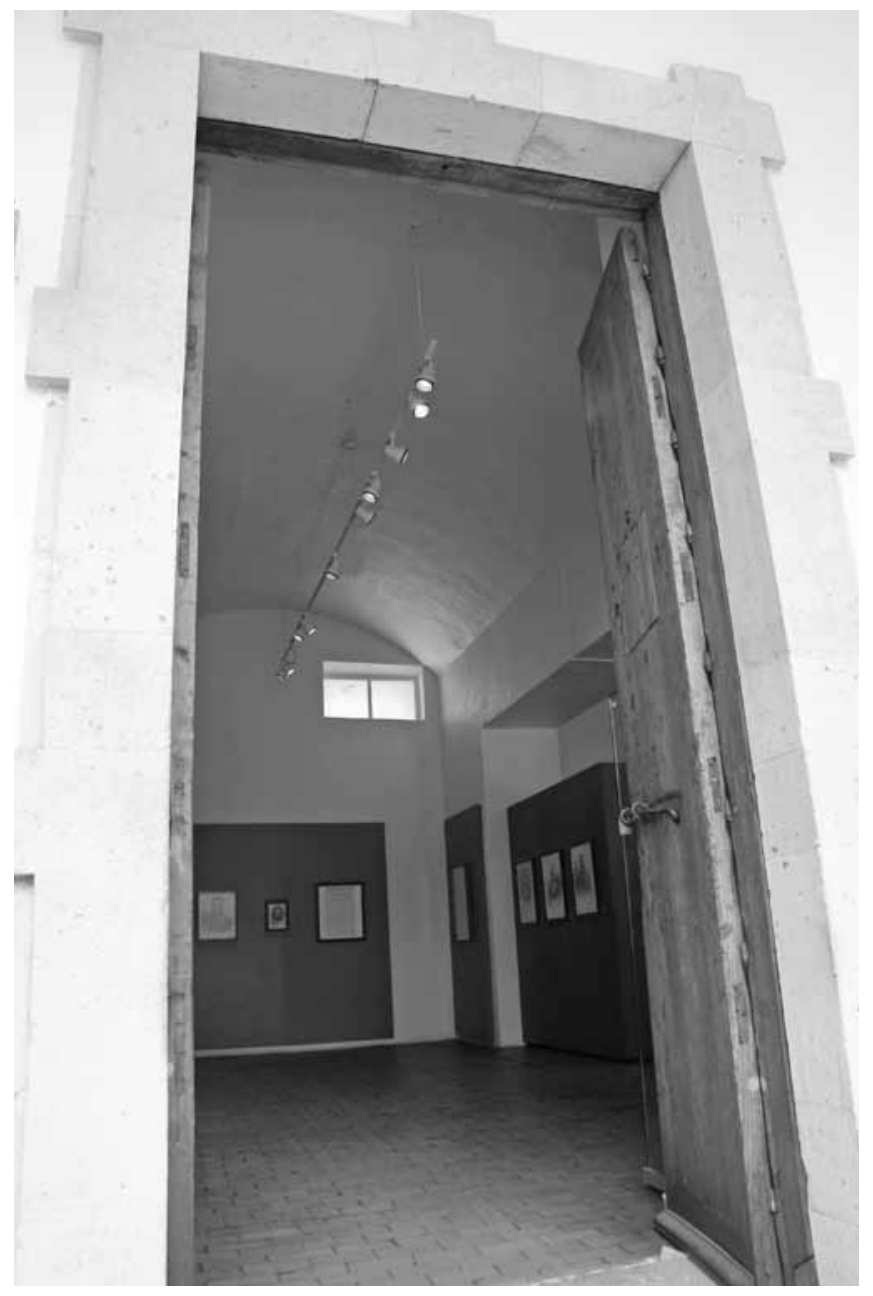

Figure 5. Granary of Granaditas, Guanajuato. Troje or storeroom Reproduction authorized by the Instituto Nacional de Antropología e Historia (Photo: author). 
to Mazo, the main errors in Durán's project related to the interior layout of spaces and rooms. For instance, Mazo felt the two stairways would interfere with the movement along the corridors and should be moved; he found their "open" location in the patio inconvenient in case of rain; and he argued that it would prove too costly to construct them as planned while ensuring their solidity. ${ }^{39}$ Mazo reduced the number of stairways to just one and pared down the size and number of some secondary rooms, such as the fiels offices and the rooms to sell the grain. He suggested the extra space be used to erect larger storerooms.

Mazo's designs consisted of three plans, two cross sections, and two elevations of the south and north façades. Though these seven designs are now lost, Mazo provided a written report that outlines his proposed amendments in detail. The total number of storerooms was reduced to seventy. Among other elements that Mazo modified were the tile roofs covering the windows: he proposed slanting the holes of these openings in order to prevent the rain from entering the storerooms. In his report, Mazo wrote he believed the storerooms should be built in accordance with values of "solidity, convenience, and beauty;" solidity, for they could "resist the thrust and weight of the maize;" convenience, since they would allow the storage of up to 200 fanegas or bushels of grain; and beauty, because they would be built "mostly in ashlar masonry." 40 Mazo's statement indicates his knowledge of Vitruvius's canons of architecture (firmitas, utilitas, venustas) and of his advice regarding the construction of public buildings. ${ }^{41}$

Nearly a month later, Mazo's report and new designs had not yet arrived in Guanajuato. This lack of response from the viceregal capital seems to have exasperated the municipal authorities, who, appealing to the viceroy's "condescension" and to his interest in the granaries and the common good, repeated their request for a licence to begin construction. Finally, on 14 March, the Junta Superior de Hacienda (chief finance committee) in Mexico City granted permission to build the alhóndiga

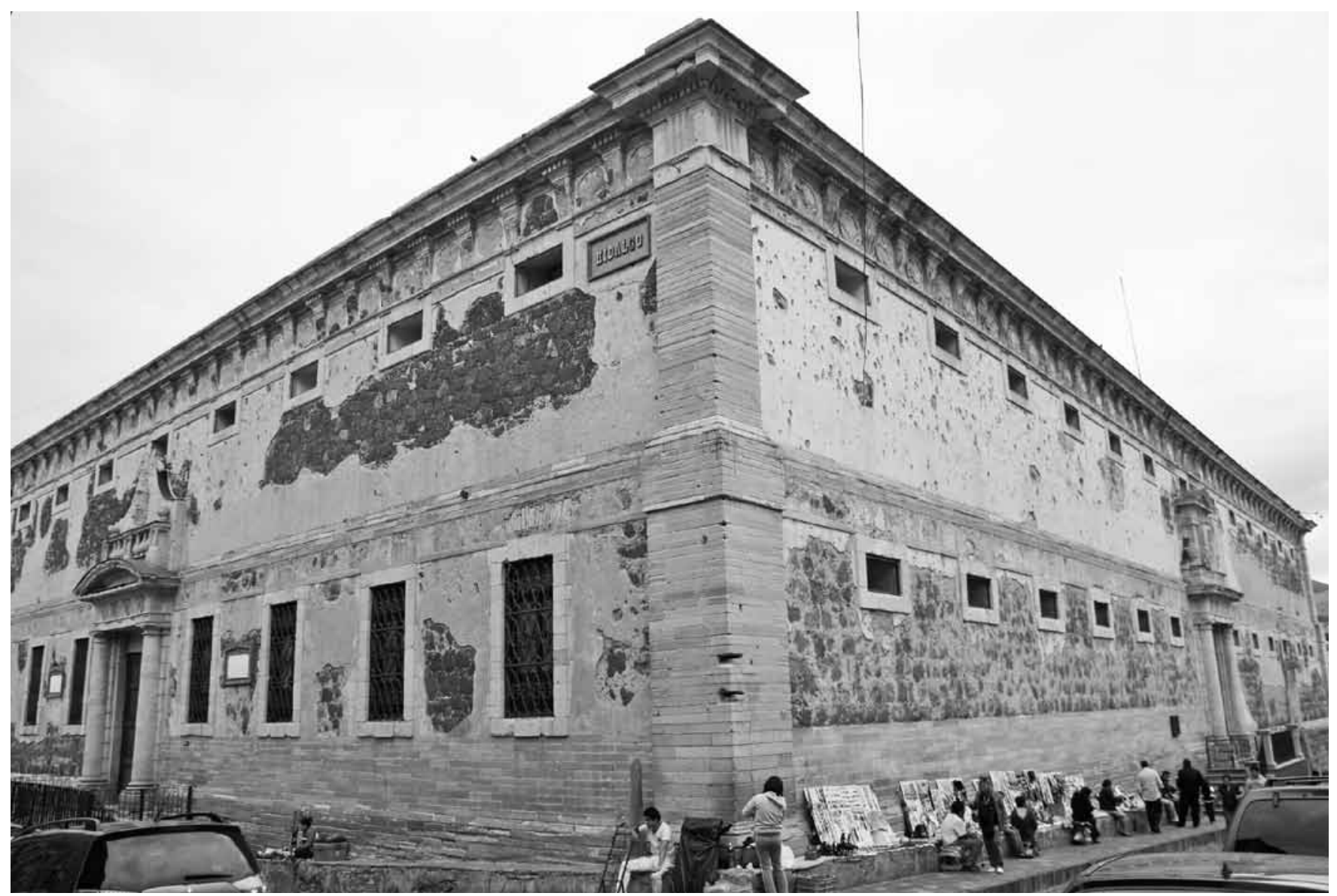

Figure 6. Granary of Granaditas, Guanajuato. East and north façades (Photo: author). 


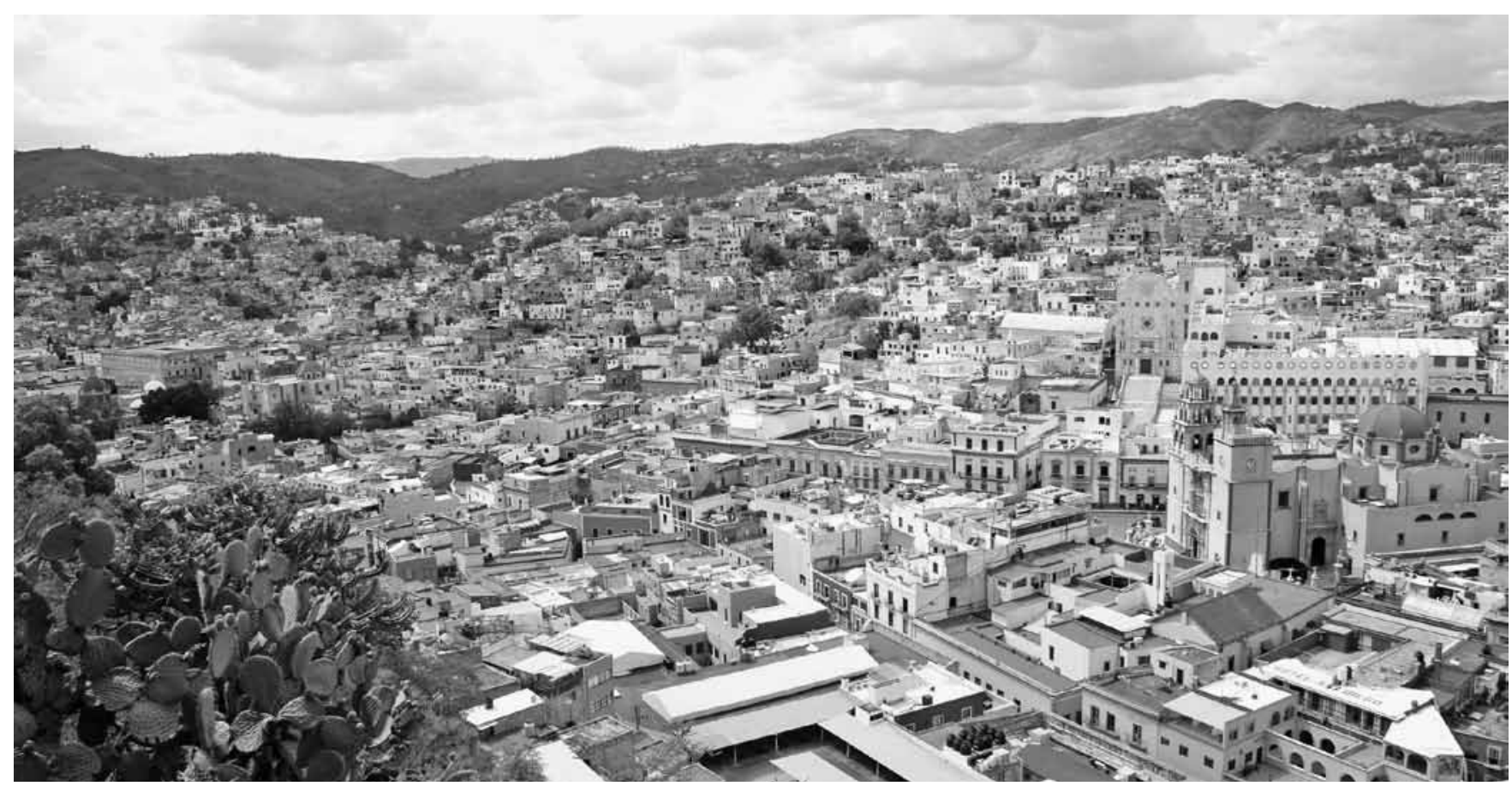

Figure 7. View of the granary of Granaditas (upper left) and the city of Guanajuato from the Hill of San Miguel (Photo: author).

"according to the plans and cross sections drawn by the Maestro Mayor de Arquitectura in this noble city, Mr. José del Mazo y Avilés," and to finance the construction as requested. The project had to be announced, both in Guanajuato and in Mexico City, for the competition of potential architects. Since the new granary would be beneficial for the local mining industry, the chief finance committee also required the provincial council of mining to be informed and urged to collaborate in the funding. 42 The complete file, including the new designs, was sent to Riaño a few days later by Baltasar Ladrón de Guevara. ${ }^{43}$ Though permission was granted, however, the licence was only issued a few months later, on 7 July.

\section{Construction and Direction of Works: Ortiz de Castro and Trinidad Pérez}

The earliest "weekly reports of the building" indicate that construction on the new alhóndiga began some time between 30 December 1797 and 5 January 1798. Close to a year later, in November 1798, Mazo travelled to Guanajuato "by request of the most illustrious city council." According to Mazo's own testimony, the purpose of his eighteen-day visit was to "establish the executive direction of the new building, the plans of which I designed." $44 \mathrm{He}$ oversaw the preliminary operations of digging and laying the foundation walls of the granary, as well as the planning and opening of two adjacent streets that would provide convenient access to the building. In the intervening months, Julián de Larín and Salvador de Retegui, commissioners elected by the city to oversee the construction of the new granary, ${ }^{45}$ had been laying the groundwork for these tasks by acquiring properties around the Granaditas site that could be used for the building and surrounding urban space. 46

The new granary contributed greatly to the urban enhancement of Guanajuato. This had been a major concern for the city council members, as recorded by municipal clerk José Ignacio Rocha in the minutes of their meetings between 1797 and 1803 . The building of the new granary and the planning of several wide streets around it would introduce much needed order into Guanajuato's chaotic urban space and particularly to the San Roque barrio (district), where the granary would be located (fig. 7). This attempt to reshape-with a symmetrical, classical, and monumental architecture-part of Guanajuato's irregular urban landscape, a legacy of its origin as a mining town, was in itself an enlightened objective. It was connected to the interest of late eighteenth-century intellectuals and Neoclassical architects in the uniformity, regularity, and embellishment of the urban space, as well as their belief that the new architecture, particularly the public buildings, could assist in the common good. 


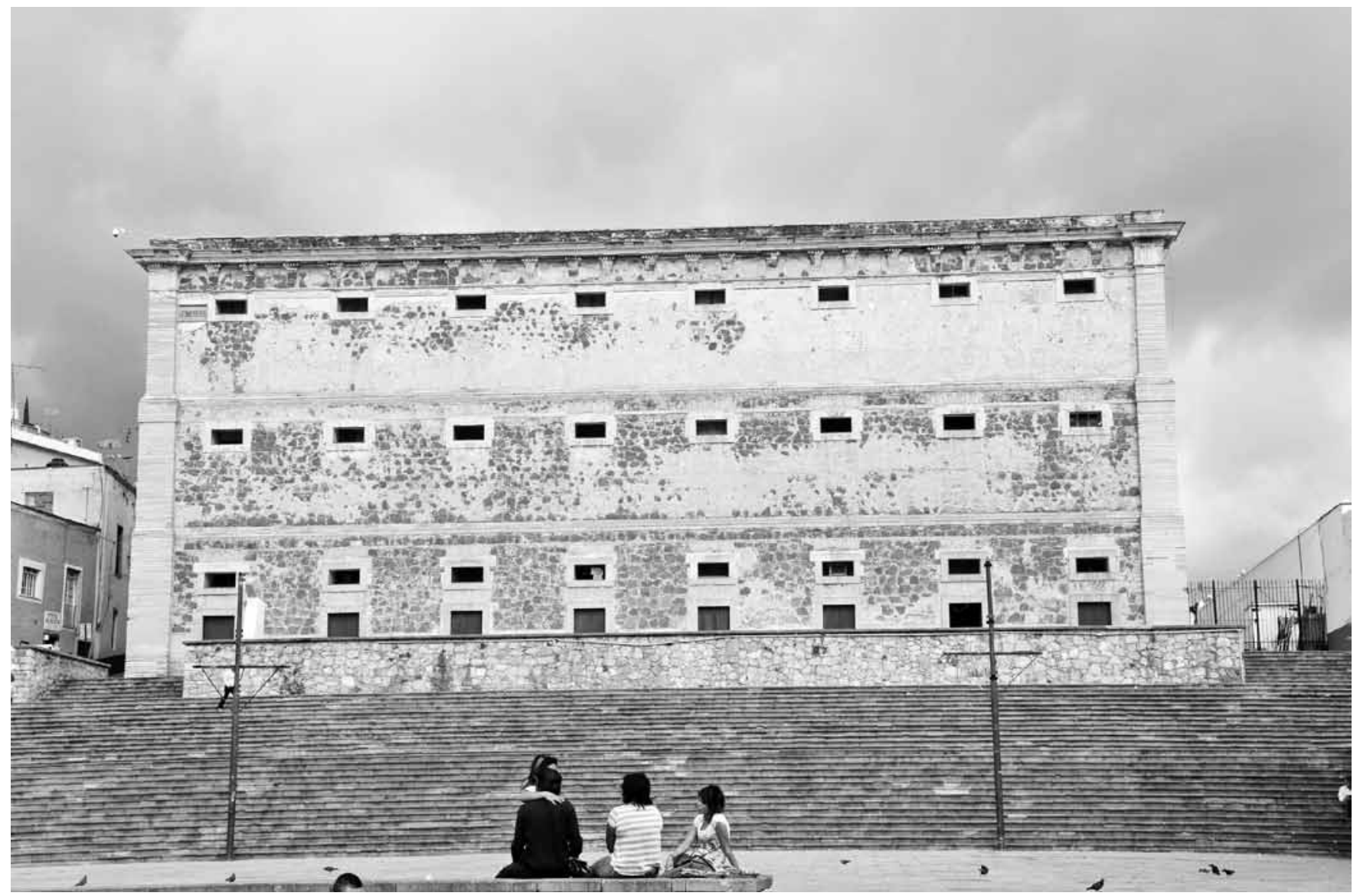

Figure 8. Granary of Granaditas, Guanajuato. West façade (Photo: author).

As soon as excavations began, Mazo and the city commissioners realized the previous budget would be vastly insufficient. Through various trial excavations, Mazo concluded that the land consisted of three types of stone: a "rock solid stone," "tepetate [a soft-stone] composed of consistent and solid particles but friable in their union," and a stone "halfway between these two extremes." Mazo added the cost of the tools and powder needed for the excavations to the price of the houses and land site purchased. His new budget for the completion of the granary amounted to 53,000 pesos more than the one originally planned by Durán, and for which the viceregal licence had been granted. ${ }^{47}$

There is not much information about the building of the alhóndiga in the following seven years, between December 1798 and November 1805. The construction of the granary and purchase of neighbouring houses continued, in accordance with Mazo's indications and estimated budget. 48 The year 1803 was full of memorable events for the city and province of Guanajuato, especially for its most distinguished and wealthy residents. Between 19 and 24 June, Viceroy José de Iturrigaray visited the city. He was greeted triumphantly and honoured by the leading personalities of the city, and he resided in the palace of Count Pérez Gálvez. Although news of the viceregal visit was not broadcast outside the city, Riaño and the city council carefully organized the customary ceremonial displays. And while the viceroy's trip was mostly organized so that he could see Guanajuato's mines and haciendas, he also visited several churches, barracks, the municipal prison, and the alhóndiga of Granaditas building site. A few weeks later, on 8 August, Guanajuato played host to another distinguished visitor, the geographer and naturalist Alexander von Humboldt. 49

In November 1805, Rafael Miera and José Miguel Septién, commissioners of public works in Guanajuato, prepared a file summarizing the state of the work on the granary and the money already spent. As expected, the commissioners concluded it would be impossible to complete the building within Durán's estimated budget, 17,000 pesos of which remained. 


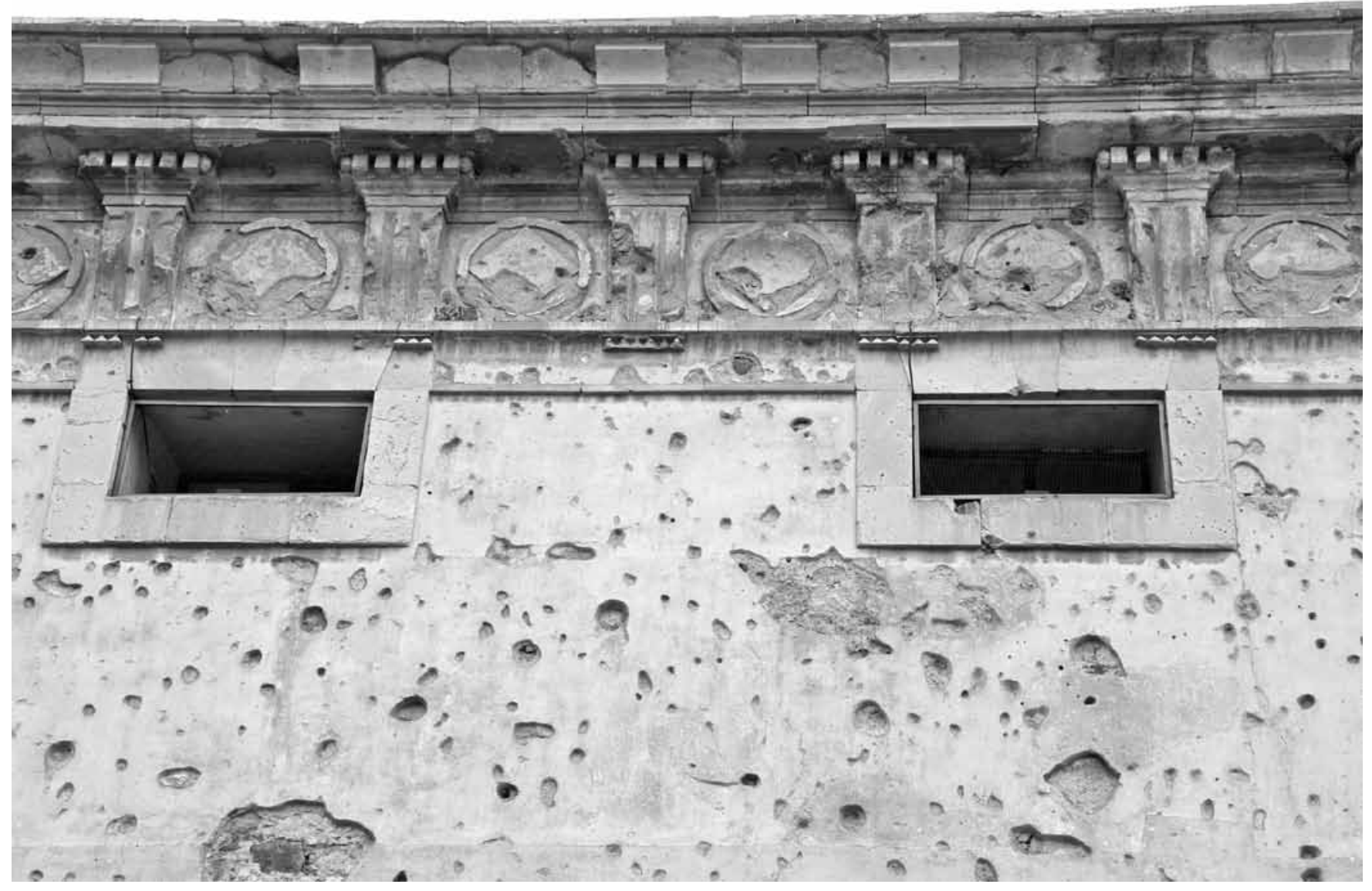

Figure 9. Granary of Granaditas, Guanajuato. Cornice with triglyphs and metopes crowning the façades (Photo: author).

The city council then requested a detailed report from the commissioners, which would describe the work already done and what remained to be executed, hoping to obtain a new licence and to extend the budget granted by the viceregal authorities. The faltas (unfinished parts of the construction) affected the entire building both structurally and decoratively, but they were mainly inside the building rather than outside. Following this report, the city council entrusted the Procurador General of the city together with Francisco Ortiz de Castro and Juan de Dios de la Trinidad Pérez, the architects in charge of constructing the building, to examine the work on the granary, provide information on what remained to be done, and estimate the cost of completion. 50

Trinidad Pérez was very active in the province of Guanajuato during Riaño's term. In 1792, he had been responsible for the designs and first budget for the renovation of the casas reales. 51 Ortiz de Castro, who is cited in 1805 as "academician supernumerary of the Royal [Academy] of San Carlos," came from a family of architects that included his father José
Martín Ortiz and his famous brother José Damián Ortiz de Castro. ${ }^{52}$ In 1804, a year before being appointed to work on Granaditas, he had participated in the building of an alhóndiga in Querétaro. 53

On 11 January 1806, Ortiz de Castro and Trinidad Pérez presented their very detailed report "in seven useful sheets." 54 Among other things, it recommends the patio be surrounded by forty columns. The building plan published by Alamán in 1849 shows that this is the quantity that was built-hence neither the thirty-two columns originally planned by Durán nor the forty-eight mentioned in Miera and Septién's 1805 report. Mazo's earlier designs were therefore not followed to the letter, as can also be seen in the retaining of the original idea of two stairways and in the removal of the fiels rooms to the exterior of the building.

Alamán described the exterior of this monumental alhóndiga as an austere building that "has no other ornament than the windows open on top of each storeroom, which gives it the sense of a castle or fortified house"55 (fig. 8). Despite its 


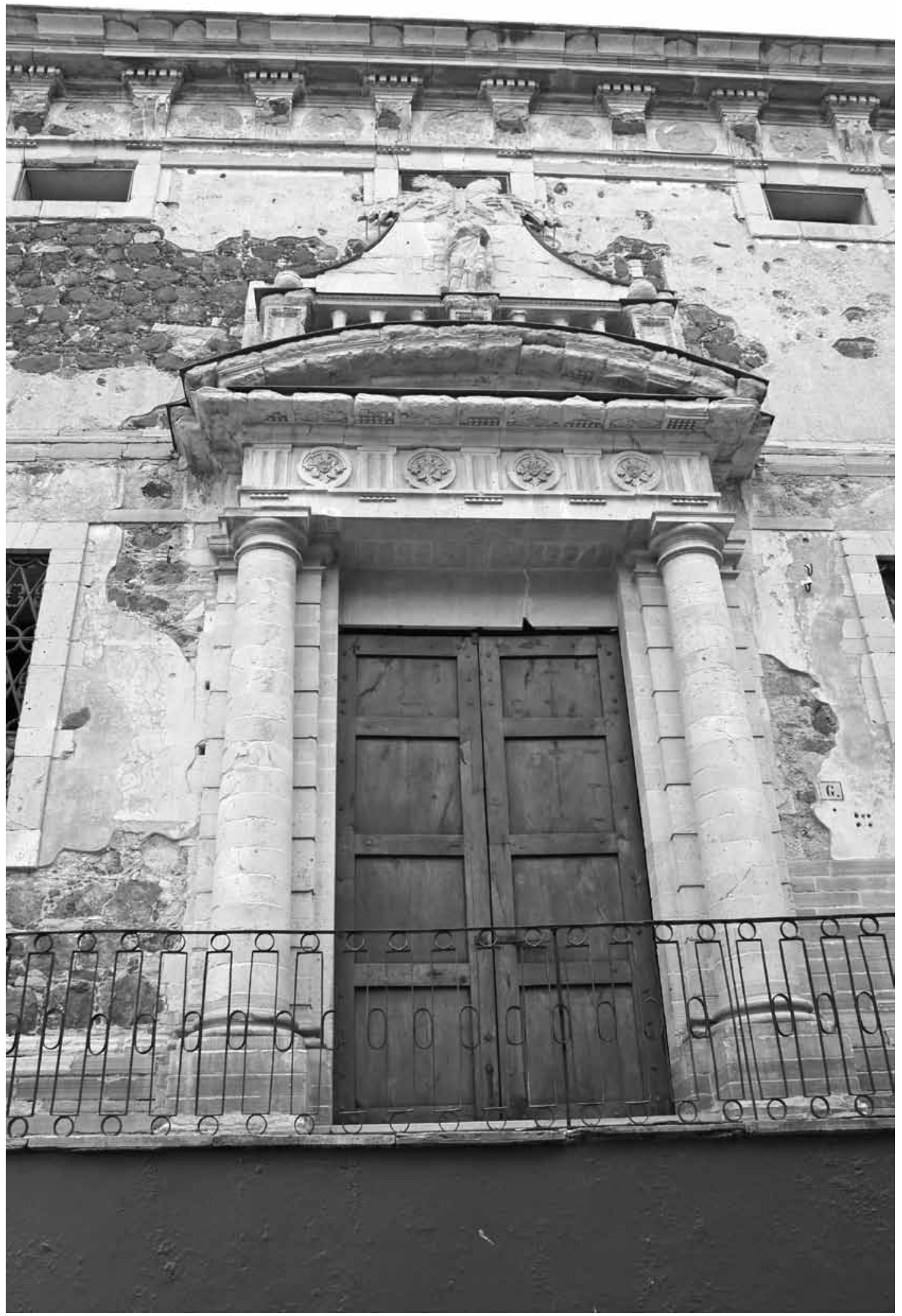

Figure 10. Granary of Granaditas, Guanajuato. East portal adorned with a sculptural relief (Photo: author). 
fortress-like appearance, the Guanajuato granary is built in an unquestionably Neoclassical style. This is visible in some of the building's architectural elements, clearly borrowed from Vitruvius's Ten Books on Architecture and Vignola's Rule of the Five Orders of Architecture, and it can also be inferred from Ortiz de Castro and Trinidad Pérez's report. 56 The exterior features a simple succession of openings, a sober "Doric cornice," as Alamán put it, with triglyphs and metopes, and two magnificent façades with corresponding classical orders, entablatures, and pediments (fig. 9). Sculptural vases and reliefs adorn the top of these doorways: one relief represents "the arms of the city carved in a medallion," and the other, dedicated to the Roman goddess of agriculture Ceres, symbolizes the abundance of grain (figs. 10, 11).57 Inside, the splendid two-storey patio most clearly displays the adoption of geometric shapes and classical elements consistent with enlightened rationalism. Lintels, balustrades, and Doric-Tuscan columns are carved meticulously for this interior space. The voluptuous forms and decorative excesses of the Baroque have given way to simple and rational ornamentation, such as "the small decorative elements of drops made of hewn stone" over the lintels in the patio (fig. 12). 58

A large file consisting of Ortiz de Castro and Trinidad Pérez's report on the state of the granary's construction and cost of completion, and the testimonies of six neighbours who expressed the urgent need for this building, was sent to Viceroy Iturrigaray in Mexico City on 27 January 1806 to request permission for a budget extension. 59

\section{Epilogue: Manuel Tolsá and the Completion of the Alhóndiga}

A month and a half later, on 7 March 1806, Riaño sent Iturrigaray a ninety-nine-page file on Guanajuato. Hoping to influence the viceroy's decision in favour of the new licence, Riaño described the events surrounding the building of the granary and appealed to Iturrigaray's benevolence. He assured the viceroy that everything related to the construction had been carried out correctly and that he had personally confirmed "the economy, order, and zeal with which this illustrious city council has accomplished its duties." Riaño claimed he had been involved in the entire process and was visiting the site daily, attending even "to the minor works." He stated that he therefore supported the city council's petition. But he raised the following dilemma: without a licence, the building would be left incomplete, and all that had been spent on it would be "uselessly [lost]," as would "the favourable benefits of its intention." 60

On 21 March, after analyzing the request from Guanajuato, the Contaduria General (general accounting office) in Mexico City informed the viceroy of its favourable opinion regarding the new expenditures, and recommended that the licence be granted. Nevertheless, the viceroy delayed his permission for several months. During this time, there was a further exchange of reports, petitions, and letters between Mexico City and Guanajuato. On 23 April, the Junta Superior de Real Hacienda requested that Riaño send them "the plans and cross sections of the alhóndiga, clearly distinguishing on them what is built and what remains to be done."61 Riaño, however, had included these drawings in the ninety-nine-page report he had sent to Mexico City. He therefore had to write back to the viceroy, requesting the drawings be returned to Guanajuato. As soon as he received them, Riaño commissioned Trinidad Pérez to carry out the task required by the Junta. In order to facilitate the comparison between what had been completed and what remained to be done, he drew "the new elevations and cross sections of the city's alhóndiga" and attached them "to the original ones drawn by José del Mazo y Avilés." Trinidad Pérez completed his report on 12 July. Two days later, in haste, Riaño sent Iturrigaray the drawings. ${ }^{62}$

On 7 August 1806, these drawings embarked on a new journey, though shorter this time, towards the Royal Academy of San Carlos in Mexico City. Despite his good relationship with the Guanajuato city council and his presumed favourable opinion on the granary construction, Iturrigaray, together with the Junta, felt it was necessary to obtain yet another expert assessment of the construction and its cost. The Mexican academy was, at that moment, the most authoritative institution in the viceregal capital regarding matters of art and architecture, and the authorities turned to them for an appropriate figure to issue a new opinion. ${ }^{63}$ The entire file was sent to Manuel Tolsá, the academy's director of sculpture, soliciting his opinion "in view of what was done and what remains to do, the amount invested and what is now requested," as well as "what can be saved by avoiding the superfluous," the "unnecessary expenses," and other "overspending." By then, Tolsâs expertise in artistic matters was unquestioned in Mexico. In addition to his celebrated equestrian statue of King Charles IV, erected in Mexico City's Plaza Mayor in 1803, his participation in several buildings and projects had contributed to the consolidation of his architectural career and reputation. Among them, and almost coincident with the building of Guanajuato's granary, is the monumental School of Mines in Mexico City, an extraordinary testimony of Neoclassical architecture in Spanish America.

On 20 September 1806, Tolsá rendered a favourable opinion. The viceroy and the Junta finally granted the licence requested and ordered that the complete file, including all the drawings, be sent back to Guanajuato. ${ }^{64}$ Tolsás report was brief, but significant. He praised the accuracy and clarity of the plans and stated that the ones 


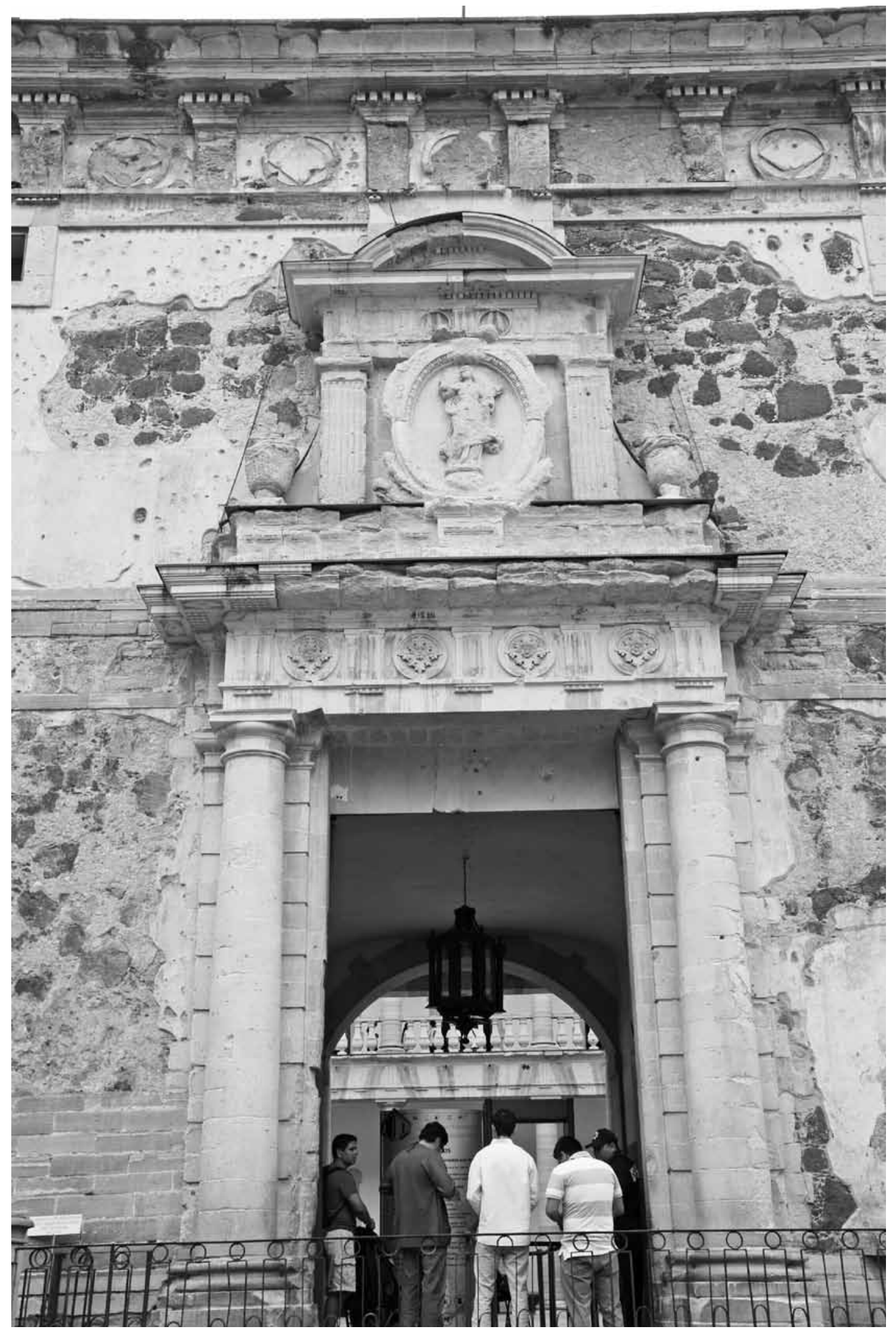

Figure II. Granary of Granaditas, Guanajuato. North portal adorned with a sculptural relief (Photo: author). 
drawn on January 1797 by architect Don José del Mazo give a true knowledge of the magnitude of the building. The newly formed [plans] designed by architect Don Juan de Dios Pérez, who is directing the work that remains to be done, as well as the budget prepared by him in association with Don Francisco Ortiz, leave no doubt [about the intentions of the city and the architects].

Tolsá opined that the building, as planned, "with the solidity and simple character that corresponds to [its] purpose," displayed "no luxury" and "nothing superfluous." With this statement, Tolsá not only validated the work of the architects who planned and executed the alhóndiga, but also that of Riaño and the Guanajuato municipal authorities, who had unconditionally supported the construction and cost of the new granary. Tolsás approval went as far as to state that "although the stone balustrade along the main corridors is richer [and more expensive] than an iron one, the extra cost...is so small that it is not worth changing or removing." What is more, he felt that the public benefit represented by the alhóndiga also justified its size and interior storerooms, which he believed to be "indispensable." He therefore considered it absolutely necessary to complete the construction. The happy news of the viceregal licence arrived in Guanajuato in early October 1806.

Three years later, in November 1809, Commissioner Larín informed Royal Lieutenant Fernando Pérez Marañón, member of Guanajuato's city council, of the completion of the granary's last finishing touches and adornments. Pérez Marañón thanked Larín for his efficient and committed work in overseeing the construction of the alhóndiga, and entrusted him to officially hand over the building to Rafael Miera, Guanajuato's alderman and commissioner of public works. With its final cost amounting to 218,263 pesos, ${ }^{65}$ the new granary of Granaditas was ready to fulfill its duties.

\section{Notes}

Unless otherwise indicated, translations are mine. I would like to express my gratitude to Aléna Robin, Luís de Moura Sobral, Ersy Contogouris, and the anonymous peer-reviewer of my manuscript for their constructive criticism and editorial guidance; to Susan Deans-Smith for introducing me to Bourbon New Spain; to José Luis Lara Valdés for sharing his invaluable knowledge of Guanajuato; to Eréndira María Guadalupe Guzmán Segoviano and the staff of the Archivo Histórico de la Universidad de Guanajuato for their generous assistance; and to my wife Kathleen Adams for her support.

1 Lucas Alamán, Historia de Méjico desde los primeros movimientos que prepararon su independencia en el año de 1808 hasta la época presente, 2 vols. (Mexico City, 1849), I, 412.

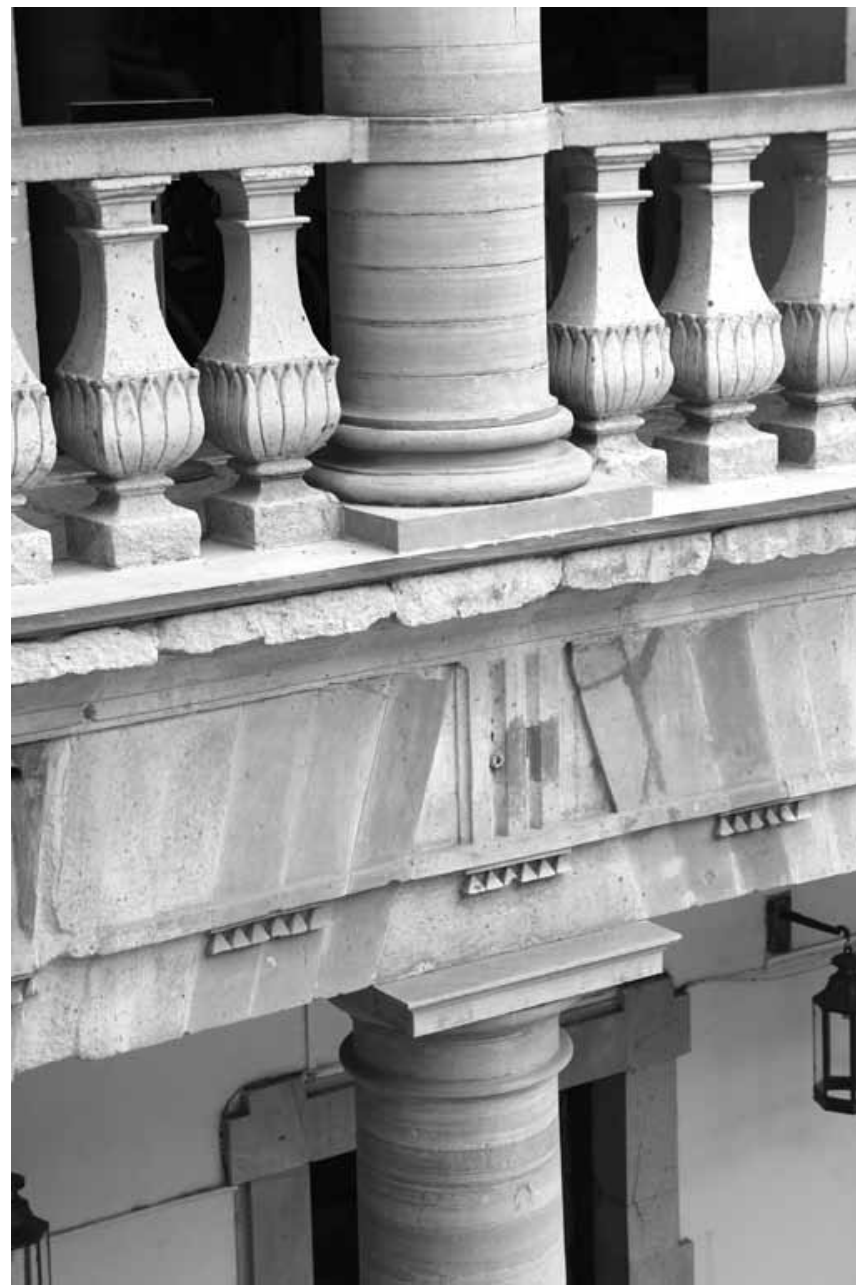

Figure 12. Granary of Granaditas, Guanajuato. Patio's columns, entablatures, and balustrade. Reproduction authorized by the Instituto Nacional de Antropología e Historia (Photo: author).

2 In 1949 the granary was turned into a museum dedicated to the history of Guanajuato. See Rosalía Aguilar Zamora and Marta Alicia Echeverría Mercado, eds., Alhóndiga de Granaditas. 200 años de historia (Guanajuato, 2010), 42.

3 In the early twentieth century, American scholars Sylvester Baxter and Percy F. Martin described the so-called "Castillo de Granaditas" without paying much attention to the building's artistic value, which was eclipsed by the historical events that occurred there during the initial episodes of the Mexican War of Independence and by the fact that by then it was used as a prison. Martin described the granary as "a perfect square, flat-roofed, solid-looking building, not in the least suggestive of anything else but what it is-a gaol. The building itself is not particularly gloomy except 
from the outside, the interior being formed of the usual 'patio,' with different departments, devoted to various trades followed by the prisoners, opening off it. The centre of the patio is occupied by a large square basin of water, wherein the prisoners are compelled to bathe and indulge in what, to the most of them, at least, must be the novelty of a cold shower." Percy F. Martin, Mexico's Treasure House (Guanajuato). An Illustrated and Descriptive Account of the Mines and their Operations in 1906 (New York, 1906), 20.

4 José Arenas Sánchez, Historia de la alhóndiga de Granaditas (Guanajuato, 1966).

5 Luis Chávez Orozco, ed., Documentos sobre las alhóndigas de Celaya, Guanajuato y Oaxaca (Mexico City, 1955), 13-14, 17.

6 Archivo General de la Nación [AGN], Mexico City, Ayuntamientos, vol. 162, ff. 4v. $-5 \mathrm{r}$.: "Informe de la concesión y origen de los Propios y Arbitrios de esta ciudad de Sta. Fe de Guanajuato. 1793.” This older municipal granary in the Calle de Alonso is number 14 in a 1750 printed view of the city drawn by José Rozuela Ledesma and entitled Plano topográfico de la Ciudad de Guanajuato. See José Luis Lara Valdés, La ciudad de Guanajuato en el siglo XVIII. Estudio urbanistico y arquitectónico (Guanajuato, 2001); Salvador Díaz-Berrio Fernández, "Plano topográfico de 1750. La importancia del agua en la ciudad de Guanajuato," Diseño y Sociedad 18 (2005): 79.

7 María del Carmen Carreón Nieto, "Desastre en Guanajuato: La inundación del 5 de julio de 1760," Tzintzun. Revista de Estudios Históricos 45 (2007): 11-32; Carlos Ruiz Medrano, "El tumulto de 1767 en Guanajuato," Estudios de Historia Novohispana XIX, 19 (1998): 17-46.

8 In a report sent to the viceroy on 17 July 1760, the city council detailed the damages caused by the floods on the evening of 5 July. In addition to the collapse of many private residences and a number of churches, some of the streets "were ruined and completely destroyed," among them, the Calle de Alonso, the street where the municipal granary was located at that time. See Lucio Marmolejo, Efemérides Guanajuatenses o datos para formar la historia de la ciudad de Guanajuato: obra escrita con presencia de los más auténticos e interesantes documentos (Guanajuato, 1883-84), II, 92-93, 99-101.

9 AGN, Ayuntamientos, vol. 194, "Expediente promovido por el Ayuntamiento de Guanaxuato sobre ser necesario componer la Alondiga de aquella ciudad," in Luis Chávez Orozco, ed., Más datos para la historia de la alhóndiga de Guanajuato (Mexico City, 1956), 2-4.

10 Chávez Orozco, Más datos, 5-8.

11 Chávez Orozco, Más datos, 9-17.

12 Enrique Florescano, Precios del maiz y crisis agricolas en México (1708-1810) (Mexico City, 1969), 140-79.

13 Marmolejo, Efemérides Guanajuatenses, II, 321, 325.

14 José Luis Caño Ortigosa, El cabildo de Guanajuato y sus relaciones institucionales (1660-1800) (Seville, 2011), 111-12.
15 Archivo General de Simancas [AGS], Valladolid, Secretaría del Despacho de Guerra, legajo 6946, exp. 22, f. 194r. See also Áurea Commons, Las Intendencias de la Nueva España (Mexico City, 1993), 16-26.

16 In 1784, Riaño had married Victoria Saint-Maxent, the daughter of a prominent merchant of New Orleans and sister-in law of three unique figures in the Spanish American administration: Luis de Unzaga y Amézaga, Bernardo de Gálvez, and Manuel de Flon. Luis de Unzaga y Amézaga (1721-90)—married to Marie Elizabeth Saint-Maxent, Riaño's sister-in-law-occupied the positions of governor of Spanish Louisiana (1770-77), captain general of Venezuela (1777-82), and governor of Cuba (1782-85). Bernardo de Gálvez (1746-86) was married to another sister of Riaño's wife, Felicité. He was also the son of Matías de Gálvez y Gallardo, viceroy of New Spain, and the nephew of another prominent figure in eighteenth-century Spain, José de Gálvez, minister of the Indies during the reign of King Charles III. Bernardo succeeded Unzaga as governor of Louisiana (1777-85), before becoming viceroy of New Spain in 1785-86. Finally, Manuel de Flon y Tejada (1745-1811) also married another of the Saint-Maxent sisters, María Ana. In 1781, under the command of their future brother-in-law Bernardo de Gálvez, Flon and Riaño participated in the battle of Pensacola against the British army. Between 1785 and 1811, Manuel Flon occupied the position of intendant of the province of Puebla. See Eric Beerman, "Juan Antonio de Riaño: Ilustre marino montañés y su participación durante la Revolución Norteamericana," Santander y el Nuevo Mundo, Segundo Ciclo de Estudios Históricos de la Provincia de Santander, Octubre 1977 (Santander, 1977), 639-50; Eric Beerman, "History and Genealogy of Juan Antonio de Riano, 1757-1810," New Orleans Genesis XVIII, 69 (January 1979): 1-5.

17 Alamán, Historia de Méjico, I, 75-76. See also Jacques Houdaille, "Frenchmen and Francophiles in New Spain from 1760 to 1810," The Americas XIII, 1 (1956): 5, 11.

18 Governors of intendencias were required by the ordinances of American intendencias to improve public works. See Real Ordenanza para el establecimiento e instruccion de intendentes de exercito $y$ provincia en el Reino de la Nueva-España (Madrid, 1786), 74-85. See also Ricardo Rees Jones, El despotismo ilustrado y los intendentes de Nueva España (Mexico City, 1979), 200-01; Isabel Gutiérrez del Arroyo, "El nuevo régimen institucional bajo la real ordenanza de intendentes de la Nueva España (1786)," Historia Mexicana XXXIX, 1 (1989): 89-122; Jorge Arturo Castro Rivas and Matilde Rangel López, Relación histórica de la Intendencia de Guanajuato durante el periodo de 1787 a 1809 (Guanajuato, 1998).

19 AGN, Obras Públicas, vol. 31, exp. 13, f. 191 r.

20 Archivo General de Indias [AGI], Seville, Estado, 42, n. 5, ff. 1r.4v., 18-23 January 1797. See also Delfina López Sarrelangue, Los orígenes de la Universidad de Guanajuato (Mexico City, 1963), 29-31. 
21 AGN, Indiferente Virreinal, Caja 5128, exp. 062, and Caja 4886, exp. 096.

22 Alexander von Humboldt, Ensayo politico sobre el reino de la Nueva España (Paris, 1822), I, 124.

23 Lilian E. Fisher, "Manuel Abad y Queipo, Bishop of Michoacan," The Hispanic American Historical Review XV, 4 (November 1935): 425-47; Carlos Juárez Nieto, Morelia y su acueducto. Sociedad y arte (Morelia, 1982), 62-74.

24 We are fortunate to have an inventory of this library's 394 titles. In terms of visual arts and architecture, it is important to emphasize the presence of some remarkable books, such as the treatise on architecture by Vitruvius in an 1787 edition by José Ortiz y Sanz; the treatise on painting by Leonardo published in 1784; the "Diccionario de las Vellas Artes," attributed to Diego Antonio Rejón de Silva and published in 1788; the three volumes of Benito Bails's "Principios de Matemática" or Elementos de matemáticas, published between 1776 and 1793; and Tomás Vicente Tosca's writings on mathematics, published in nine volumes in the early eighteenth century. Regarding the history and administration of granaries, Pérez Becerra also owned a copy of Antonio Elies Rubert's 1787 Discurso sobre el origen, antigüedad y progresos de los pósitos o graneros públicos en los pueblos. See Henry Bernstein, "A Provincial Library in Colonial Mexico, 1802," Hispanic American Historical Review 26 (1946): 162-83.

25 The wealthy and ambitious Count Pérez Gálvez's interest in displaying his privileged social and economic status is reflected in the visual arts. In 1792, José María Guerrero executed a pair of portraits, currently held in a private collection in Seville, depicting Pérez Gálvez and his wife. Other illustrious viceregal and ecclesiastical figures also posed for this Novohispanic painter who was linked to the Mexican Academy of San Carlos. See Francisco Montes González, "Reflejos de una ambición novohispana. Los retratos de los I condes de Pérez Gálvez por el pintor José María Guerrero (1792)," Anales del Museo de América 16 (2009): 155-72.

26 AGI, Títulos de Castilla, legajo 7, Real Cédula 36, and legajo 3, Real Cédula 8.

27 Archivo de la Antigua Academia de San Carlos [AAASC], Mexico City. Guanajuato, 8 March 1805, in Eduardo Báez Macías, Guia del Archivo de la Antigua Academia de San Carlos, 1801-1843 (Mexico City, 1972), 17. Originally from the nearby town of Celaya, Tresguerras was the designer of some of the best examples of Neoclassical architecture in the province of Guanajuato during Riaño's term. According to Alamán, Tresguerras was an architect "whom Riaño greatly recognized and favoured" (Alamán, Historia de Méjico, I, 75-76).

28 AGN, Ayuntamientos, vol. 162, ff. 28r.-28v.: "Informe de la concesión y origen de los Propios y Arbitrios de esta ciudad de Sta. Fe de Guanajuato. 1793.”

29 Aguilar Zamora and Echeverría Mercado, Alhóndiga de Granaditas, $75-81$.
30 Archivo Histórico de la Universidad de Guanajuato [AHUG], Guanajuato, Fondo Ayuntamiento, Obra Pública, Alhóndiga (2a), Caja 3, 1793-1809, ff. 1r.-3v.

31 The first testimony was given on 2 March 1793 by José Mariano de Sardaneta y Llorente, second Marquis of San Juan de Rayas. In the following days, Juan Nepomuceno de Castro, municipal clerk, recorded the testimony of other distinguished residents of Guanajuato, including Miguel de Rivera Llorente, former alderman of the city and relative of the Count of Valenciana and the Marquis of San Juan de Rayas; the intellectual José Pérez Becerra, administrator of the royal customs in Guanajuato; Captain Antonio Pérez Gálvez, who was married to the eldest daughter of the Count of Valenciana and soon-to-be Count Pérez Gálvez himself; José Manuel Alegre, fiel or administrator of the municipal granary; Francisco Bustamante, administrator of the royal tobacco factory in Guanajuato. See David Brading, Miners and Merchants in Bourbon Mexico 1763-1810 (Cambridge, 1971), 242, 308-09.

32 AHUG, Alhóndiga (2a), Caja 3, 1793-1809, ff. 3v.-26r.

33 AGN, Alhóndigas, Caja 5761, exp. 024, f. 4v.

34 In January 1793, Durán had also examined the old casas reales in Guanajuato for their projected renovation (See AGN, Instituciones Coloniales, Ayuntamiento, Obras Públicas, vol. 31, exp. 13, ff. 209r.-211r.).

35 AHUG, Alhóndiga (2a), Caja 3, 1793-1809, ff. 27r.-28v.

36 AHUG, Alhóndiga (2a), Caja 3, 1793-1809, ff. 31r.-36v.

37 Mazo replaced José Damián Ortiz de Castro in 1794 as Segundo Maestro Mayor de Arquitectura of Mexico City. See Xavier Moyssén, "Los arquitectos de México y el monopolio de la cal en 1794," Estudios de Historia Novohispana IV, 4 (1971): 151-62; Eduardo Báez Macías, "José del Mazo y Avilés: proyectos de arquitectura civil e intervención en la capilla del Tercer Orden del Carmen," Retablo barroco a la memoria de Francisco de la Maza (Mexico City, 1974), 173-80; Thomas Brown, La Academia de San Carlos de la Nueva España (Mexico City, 1976), II, 84-86; Sonia Lombardo de Ruiz, "La construcción y los constructores: Metodología en el estudio de los estilos arquitectónicos de la ciudad de México (1780-1805)," Anales del Instituto de Investigaciones Estéticas 46 (1976): 71-79; Elizabeth Fuentes Rojas, La Academia de San Carlos y los constructores del Neoclásico. Primer catálogo de Dibujo Arquitectónico 1779-1843 (Mexico City, 2002), 32-35; Delia Pezzat Arzave, Catálogos de Documentos de Arte 28. Archivo General de la Nación, México. Ramos: Policía, Ayuntamientos, Caminos y Calzadas (Mexico City, 2002), 62.

38 AHUG, Alhóndiga (2a), Caja 3, 1793-1809, f. 41 r.

39 AHUG, Alhóndiga (2a), Caja 3, 1793-1809, f. 39r.

40 AHUG, Alhóndiga (2a), Caja 3, 1793-1809, ff. 39r.-41r.

41 Mazo's words highlight a major and unresolved question regarding his architectural education and access to written sources. In the eighteenth century, two new editions of Vitruvius's treatise on architecture appeared in Spain. The first one, translated 
from Claude Perrault's French version, was edited in 1761 by academician José de Castañeda for use by the students of the Royal Academy of San Fernando in Madrid. The second edition was translated into Spanish by intellectual José Ortiz y Sanz and published in 1787. By the last decade of the eighteenth century, these editions were certainly known in the Mexican Academy of San Carlos and among the intellectual circles of Mexico City and Guanajuato (see note 24). Access to educational materials, including architectural treatises and prints, was a major concern for the general director of the Mexican academy, Jerónimo Antonio Gil, and for the professors of the different artistic disciplines. It should not pass unnoticed that, upon his arrival to Mexico from Spain on 22 July 1791, architect and sculptor Manuel Tolsá brought seventysix chests containing books and diverse artistic material, including plaster casts from classical sculptures in Madrid's Academy of San Fernando and in the Vatican. Architectural books and artistic treatises by Vitruvius, Serlio, Vignola, Durero, Pacheco, Palomino, and Ripa, among others, were already used in Mexico for educational purposes, as listed in a 1786 inventory of teaching materials. See José Enrique García Melero, Literatura española sobre artes plásticas. Volumen I: Bibliografía aparecida en España entre los siglos XVI y XVIII (Madrid, 2002), 38-53; Francisco Almela y Vives and Antonio Igual Úbeda, El arquitecto y escultor valenciano Manuel Tolsá (1757-1816) (Valencia, 1950), 54-55; Carlos Chanfón Olmos, ed., Historia de la arquitectura y el urbanismo mexicanos (Mexico City, 2004), 179-84; Kelly Donahue-Wallace, "El grabado en la Real Academia de San Carlos de Nueva España, 1783-1810," Tiempos de América 11 (2004): 53.

42 AHUG, Alhóndiga (2a), Caja 3, 1793-1809, ff. 68r.-80r.; AGN, General de Parte, vol. 76, exp. 52, ff. 40r.-41r.

43 Magister Baltasar Ladrón de Guevara stood out for his determination to resolve several issues related to the cleanliness, order, and urban regulations of the viceregal capital. He is the attributed author of a memorable 1788 volume on the problems of Mexico City in this matter and the necessary measures to be adopted. See Delfina López Sarrelangue, "La policía de la ciudad de México en 1788," in Estudios sobre la ciudad iberoamericana, ed. Francisco de Solano (Madrid, 1983), 227-40; Ignacio González-Polo, ed., Reflexiones y apuntes sobre la Ciudad de México: fines de la colonia (Mexico City, 1984).

44 AHUG, Alhóndiga (2a), Caja 3, 1793-1809, ff. 85r.-86r.

45 AHUG, Alhóndiga (2a), Caja 3, 1793-1809, ff. 96r.-97v.

46 Over the course of the following years, while the granary continued to be erected, Larín and Retegui, as well as other appointed commissioners, acquired additional plots, stables, jacales (adobe and thatch-roofed huts), and other buildings. See AHUG, Fondo Ayuntamiento, Administración de Escribanías, Protocolo de Cabildo, 1797, ff. 403r.-415r.; 1798, ff. 64r.-72r.; 1799, ff. 57v.-66v., 96r.-97v., 224r.-230r., 278r.-288r., in Arenas Sánchez, Historia de la alhóndiga, 145-73.
47 AHUG, Alhóndiga (2a), Caja 3, 1793-1809, ff. 85r.- 86r.

48 The expenses were recorded in weekly reports. Following Durán's earlier proposal, several houses belonging to José Antonio del Mazo, a resident of Guanajuato, were acquired between March and October 1803 in order to enlarge Valdés street and to ensure access to the Granaditas bridge (Arenas Sánchez, Historia de la alhóndiga, 208-11).

49 Isauro Rionda Arreguín, ed., Testimonios sobre Guanajuato (Guanajuato, 1989), 192-93.

50 AHUG, Alhóndiga (2a), Caja 3, 1805-08, ff. 2v.-3v.

51 AGN, Mapas, planos e ilustraciones, "Casa Real de Guanajuato, 1792;" AGN, Obras Públicas, vol. 31, exp. 13. In 1793, Trinidad Pérez also designed two plans for the building of the royal jail in Silao. Years later, in 1816, he was documented as a master architect in the city of Guadalajara. By then he was also working, among other projects, in the nearby town of Lagos, presenting an estimated budget for the reform of the Customs House (AGN, Mapas, Planos e Ilustraciones; AGN, Obras Públicas, vol. 37, exp. 23).

52 AHUG, Alhóndiga (2a), Caja 3, 1805-08, f. 3v.

53 In addition to Francisco Ortiz de Castro, architect Manuel Tolsá and surveyor José Mariano Oriñuela also presented their own designs for the reform of the alhóndiga in Querétaro (AGN, Obras Públicas, vol. 23, exp. 5, ff. 162r.-215v. and vol. 25, exp. 6, ff. 211r.-234r.). See also: Fuentes Rojas, La Academia de San Carlos, 273-77; Mina Ramírez Montes, "José Mariano Orińuela y su proyecto para el establecimiento de una Academia de Matemáticas en Querétaro," Anales del Instituto de Investigaciones Estéticas 97 (2010): 5-24.

54 AHUG, Alhóndiga (2a), Caja 3, 1805-08, ff. 4r.-11v.

55 Alamán, Historia de Méjico, I, 411-12.

56 Two new editions of Vignola's Five Orders of Architecture were published in Spain during the eighteenth century: one edited by Diego de Villanueva in 1764 and the other, a 1792 translation by Fausto Martínez de la Torre and José de Asensio of a French edition by architect Claude-Mathieu Delagardette. Although the files studied in this essay do not mention these books, it is reasonable to assume that José del Mazo and Francisco Ortiz de Castro were familiar with both treatises and their architectural models when designing and building the Guanajuato granary. See Marcos Vitruvio Polión, Los Diez Libros de Architectura (Madrid, 1787), plate XXXIII; Jacopo Barozzi da Vignola, Reglas de los Cinco Órdenes de Arquitectura de Vignola (Madrid, 1792), plate 39.

57 AHUG, Alhóndiga (2a), Caja 3, 1805-08, ff. 3v.-11v.

58 AHUG, Alhóndiga (2a), Caja 3, 1805-08, ff. 3v.-11v

59 AHUG, Alhóndiga (2a), Caja 3, 1805-08, ff. 12r.-19v.

60 AHUG, Alhóndiga (2a), Caja 3, 1805-08, ff. 20r.-21r.

61 AHUG, Alhóndiga (2a), Caja 3, 1805-08, n.p.

62 AHUG, Alhóndiga (2a), Caja 3, 1805-08, ff. 21v.-38r.

63 In a letter sent to Viceroy Iturrigaray a year earlier, the Academy 
of San Carlos emphasized the need to propagate "good taste in the arts and to avoid the abuse to which they are subjected, particularly in the cities and towns away from the capital, where works of painting, sculpture, and architecture are freely executed by incompetent people; this freedom has already caused the saddest consequences." See AAASC, 6 February 1805, in Báez Macías, Guia del Archivo de la Antigua, 15.

64 The history of the comings and goings of these plans designed by architects Mazo and Trinidad Pérez is remarkable. Unfortunately, the drawings are still missing. Considering the account of the events published by the Guanajuato city council in 1811, they were probably destroyed or lost during the previous year's siege of the alhóndiga. This account states that on the evening of 24 September 1810, Intendant Riaño ordered that the troops stationed in the city, the riches deposited in the Royal Treasury, and the papers preserved in the municipal archives all be transferred to the granary of Granaditas. Four days later, during the final assault on the building, "Your Majesty's, the city's, and other individuals' riches, along with many other treasures, silver, and other precious [objects], that were contained there, were stolen." See Pública vindicación del Ilustre Ayuntamiento de Santa Fe de Guanaxuato justificando su conducta moral y politica en la entrada y crimenes que cometieron en aquella ciudad las huestes insurgentes agabilladas por sus corifeos Miguel Hidalgo, Ignacio Allende (Mexico City, 1811), 14, 22-23.

65 AHUG, Alhóndiga (2a), Caja 3, 1805-08, n. p.; AHUG, Alhóndiga (2a), Caja 3, 1793-1809, ff. 99r.-103v. See Arenas Sánchez, Historia de la alhóndiga, 315-22, 383-89. Marmolejo dated the completion of the granary as 7 November 1809 , and calculated the total cost of the works to be 218,306 pesos and six reales (Marmolejo, Efemérides Guanajuatenses, III, 29). 